International Business and Global Economy 2018, no. 37, pp. 231-243

Biznes międzynarodowy w gospodarce globalnej 2018, nr 37, s. 231-243

Edited by the Institute of International Business, University of Gdańsk

\title{
Osłabienie powiązań produkcyjnych w gospodarce światowej jako czynnik spowolnienia handlu międzynarodowego w latach 2008-2015
}

Głównym celem artykułu jest próba oceny zjawiska refragmentacji produkcji i jego wpływu na spowolnienie handlu międzynarodowego w latach 2008-2015 na podstawie przeglądu badań. Kryzys finansowo-gospodarczy lat 2008-2009 spowodował największe załamanie handlu międzynarodowego w okresie powojennym. Następujące po nim ożywienie gospodarcze nie znalazło jednak odzwierciedlenia we wzroście dynamiki światowego eksportu. Jednym z wymienianych powodów stagnacji $\mathrm{w}$ wymianie jest osłabienie powiązań produkcyjnych $w$ ramach globalnych łańcuchów wartości dodanej. Uzyskane wyniki sugerują, że największy wpływ na spadek udziału zagranicznej wartości dodanej w światowym handlu, a zarazem obniżenie dochodowej elastyczności eksportu mają zmiany zachodzące w specjalizacji Chin, a przede wszystkim wzrost udziału krajowych komponentów w eksporcie.

Słowa kluczowe: handel międzynarodowy, handel wartością dodaną, fragmentaryzacja produkcji

Klasyfikacja JEL: F40, F62, G01

\section{Weakening of the production linkages in the world economy as a factor of the global trade slowdown in 2008-2015}

The main goal of the paper is to evaluate the extent of production de-fragmentation and its impact on the world trade flows slowdown in 2008-2015. Financial and economic crisis of 2008-2009 resulted in a deepest breakdown of world trade after World War II. The subsequent economic boom was not reflected in the growth rates of world exports. One of the mentioned reasons of trade stagnation is the weakening of the connections within the global value chains. The results of the analysis conclude that the biggest impact on the declining share of foreign value added in global trade and, as a consequence, decreasing income elasticity of exports stems from changes in Chinese specialization and, in particular, the growing share of domestic input in Chinese exports.

Keywords: international trade, value added trade, fragmentation of production

JEL classification: F40, F62, G01 


\section{Wprowadzenie}

Spowolnienie handlu międzynarodowego po kryzysie gospodarczym lat 2008-2009 spowodowane jest kilkoma czynnikami, wśród których najczęściej wymienia się załamanie popytu na głównych rynkach świata, tłumaczone nową sekularną stagnacją, zahamowaniem procesu liberalizacji polityki handlowej i wzrostem skali stosowanych barier regulacyjnych, spadkiem cen eksportowych oraz zmianą charakteru zależności między wzrostem gospodarczym a handlem międzynarodowym. Ostatni z tych czynników wydaje się kluczowy w wyjaśnieniu spowolnienia handlu światowego. Potwierdzają to zarówno dane historyczne, jak i analizy współczesne. W opublikowanym w 2002 r. artykule Douglas Irwin wykazał, że 1-procentowy wzrost światowego PKB w latach 1950-2000 powodował wzrost światowego handlu o 1,7\%. Ponadto stwierdził, że za wyjątkiem okresu międzywojennego handel międzynarodowy w latach 1870-2000 rozwijał się szybciej niż światowy PKB, a więc dochodowa elastyczność eksportu była wyższa niż 1 [Irwin, 2002, s. 95]. Cristina Constantinescu, Aaditya Mattoo i Michele Ruta, wykorzystując analogiczną metodę co Irwin, obliczyli, że dochodowa elastyczność eksportu w latach 2001-2007 wynosiła 1,5 i spadła do 0,7 w latach 2008-2013 [Constantinescu, Mattoo, Ruta, 2015, s. 5]. Po raz pierwszy zatem w okresie powojennym światowy handel rozwija się $w$ tempie niższym niż globalny PKB.

Jednym z prawdopodobnych powodów zmniejszenia roli handlu w procesie wzrostu gospodarczego i stagnacji $w$ wymianie jest osłabienie powiązań produkcyjnych w ramach globalnych łańcuchów wartości dodanej. Główny cel artykułu stanowi próba oceny zjawiska refragmentacji produkcji i jego wpływu na spowolnienie handlu międzynarodowego w latach 2008-2015 na podstawie przeglądu badań.

\section{Teoretyczne podstawy analizy zjawiska fragmentaryzacji produkcji}

Zmiany, jakie nastąpiły w gospodarce światowej w ostatnich dekadach, wywarły istotny wpływ na podstawy koncepcyjne i teorie handlu międzynarodowego. Przede wszystkim pojawily się próby modelowego zdefiniowania takich zjawisk, jak niedoskonała konkurencja w handlu międzynarodowym, heterogeniczność producentów czy rozwój wymiany dobrami pośrednimi. Obecnie najbardziej ożywione prace dotyczą wyjaśnienia procesu międzynarodowej fragmentaryzacji, polegającego na geograficznym podziale produkcji na zlokalizowane $\mathrm{w}$ różnych krajach zadania produkcyjne. 
Możemy wskazać trzy dominujące nurty badawcze:

1) globalnych łańcuchów wartości,

2) pionowej specjalizacji,

3) pionowej dezintegracji.

Początki koncepcji globalnych łańcuchów wartości sięgają lat siedemdziesiątych XX w. i wywodzą się z teorii systemu światowego, rozwijanej przez Immanuela Wallersteina i Terence'a Hopkinsa [Hopkins, Wallerstein, 1977; 1986]. Wprowadzili oni do literatury termin łańcuchów towarowych, który zdefiniowali jako powiązania pracy i procesów produkcji, których efekt stanowi produkt finalny. Znacznie bliższe współczesnemu nam rozumieniu łańcuchów wartości jest pojęcie globalnych łańcuchów towarowych, wprowadzone w latach dziewięćdziesiątych XX w. przez Gary'ego Gereffiego, Miguela Korzeniewicza i Roberto Korzeniewicza [1994]. Określili je oni jako sieci powiązań zorganizowane wokół jednego towaru, łączące gospodarstwa domowe, przedsiębiorstwa i państwa w ramach gospodarki światowej.

Dalszy rozwój opisywanej koncepcji związany był z pracami Gary'ego Gereffiego, Johna Humphreya i Timothy'ego Sturgeona [2005]. Opierając się na badaniach Michaela Portera nad łańcuchami wartości, wprowadzili oni pojęcie globalnych łańcuchów wartości. Rozumieli je jako proces, w którym technologia łączona jest $\mathrm{z}$ nakładami materiałowymi i pracą, a następnie przetworzone nakłady są montowane, poddawane procesowi marketingu i dystrybuowane.

Koncepcja łańcuchów, a zwłaszcza liniowośći wertykalność powiązań produkcyjnych, stanowi duże uproszczenie rzeczywistości gospodarczej. W związku z tym w ostatnich latach coraz częściej stosuje się termin "globalne sieci wartości", definiując go jako globalnie zorganizowane i połączone przez firmy i inne organizacje ogniwa funkcji i operacji, których zadaniem jest produkcja i dystrybucja dóbr i usług.

Drugim nurtem badawczym wyjaśniającym zjawisko międzynarodowej fragmentaryzacji produkcji jest pionowa specjalizacja. Ujęcie to również nie jest nowe, a jego początki sięgają lat sześćdziesiątych i siedemdziesiątych XX w. Już w 1967 r. Bella Balassa pisał o możliwości pionowej specjalizacji [Balassa, 1967], a Ronald Findlay [1978] dokonał charakterystyki pionowego międzynarodowego podziału pracy. Dotychczas w najbardziej kompleksowy sposób koncepcję tę ujęli David Hummels, Jun Ishii i Kei-Mu Yi [2001]. Ich zdaniem zjawisko pionowej specjalizacji występuje wtedy, gdy spełnione są równocześnie trzy podstawowe warunki:

1) dobro jest produkowane $w$ dwóch lub więcej następujących po sobie stadiach;

2) dwa lub więcej krajów dostarcza wartości dodanej w procesie produkcji dobra;

3) przynajmniej jeden kraj musi wykorzystywać importowane nakłady podczas swojego etapu produkcji, a część rezultatu produkcji musi być eksportowana. 
Ostatnim analizowanym nurtem badawczym, a zarazem alternatywą dla pionowej specjalizacji, jest pionowa dezintegracja, czyli outsourcing. Firmy podejmujące decyzję o internacjonalizacji działalności napotykają często fundamentalny problem: samodzielnie realizować wszystkie stadia procesu produkcji, a zatem pozostać przy pionowej specjalizacji, czy też podjąć decyzję o wertykalnej dezintegracji produkcji i zlecić część zadań podmiotom zewnętrznym. Outsourcing ma miejsce wówczas, gdy firmy decydują się kupić produkty lub usługi od zewnętrznych dostawców zlokalizowanych w kraju (outsourcing krajowy) lub za granicą (outsourcing międzynarodowy). Gdy outsourcing międzynarodowy odbywa się poprzez tworzenie zagranicznych filii (ZIB), wówczas kontrola nad procesami produkcyjnymi pozostaje w granicach firmy i możemy mówić o tzw. offshoringu na uwięzi (captive offshoring). Między firmą macierzystą a zagraniczną filią rozwijają się powiązania handlowe (handel wewnątrzkorporacyjny) i produkcyjne. Offshoring w klasycznej formie występuje natomiast wtedy, gdy firma przenosi część procesów produkcyjnych poza granice kraju, zlecając ich wykonanie podmiotom trzecim.

Nieco odmiennie do problemu pionowej dezintegracji podchodzą Ronald Jones i Henryk Kierzkowski [1990; 2001]. Nazywają oni owo zjawisko fragmentaryzacją, a proces produkcji przedstawiają jako serię bloków produkcyjnych, które mogą być zlokalizowane w różnych regionach, połączonych ze sobą usługami (administracyjnymi, transportowymi, finansowymi) [Jones, Kierzkowski, 1990, s. 31]. Początkowo produkcja odbywa się w jednej lokalizacji, a usługi służą do dostarczania i promowania produktu. Wraz z pogłębieniem specjalizacji liczba bloków produkcyjnych się zwiększa, a struktury produkcyjne przyjmują coraz bardziej złożone formy, w których produkcja odbywa się równolegle w różnych krajach.

\section{Metody pomiaru skali fragmentacji produkcji i źródła danych statystycznych}

W najpełniejszy sposób metodę pomiaru skali zjawiska fragmentaryzacji produkcji i związanego z nią handlu wartością dodaną opracowali Robert Koopman, Zhi Wang i Shang-Jin Wei [2014]. Dokonali oni dekompozycji eksportu brutto na krajową (DVA) oraz zagraniczną wartość dodaną (FVA) (rys. 1). Krajowa wartość dodana została podzielona na tę w całości konsumowaną za granicą, obejmującą zarówno dobra finalne, jak i pośrednie, lub reeksportowaną do krajów trzecich przez pierwszego importera, oraz krajową wartość dodaną, najpierw wyeksportowaną, która powróciła do kraju. Zagraniczną wartość dodaną możemy podzielić na zawartą w eksporcie dóbr finalnych i pośrednich. Ostatnią kategorią jest podwójnie liczony eksport, czyli te same produkty (krajowe i pochodzące z zagranicy) dwa i więcej razy eksportowane. 


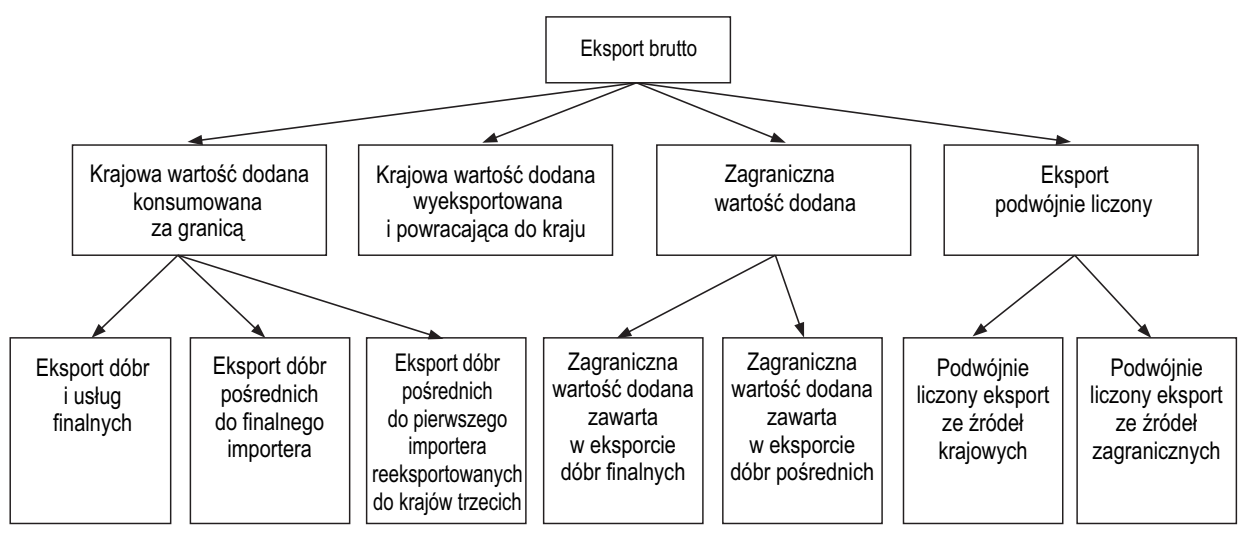

Rysunek 1. Metoda pomiaru eksportu brutto

Źródło: [Inomata, 2017, s. 25].

Jednym z najbardziej kompleksowych źródeł danych o udziale zagranicznej wartości dodanej w eksporcie brutto jest baza współtworzona przez WTO i OECD. W najnowszej edycji z grudnia 2016 r. zawiera ona informacje dla 63 krajów i reszty świata oraz zagregowane dane dla kilku regionów i ugrupowań integracyjnych [OECD-WTO, 2016]. Zakresem czasowym objęto lata 1995-2014.

Kolejny projekt, baza WIOD [2016], tworzony jest przez konsorcjum uniwersytetów i instytutów badawczych z Europy. W najnowszym wydaniu z listopada 2016 r. baza zawiera dane o źródłach wartości dodanej dla 43 krajów i reszty świata dla lat 2000-2014. Jej starsza wersja z 2013 r. zawiera dane dla 40 gospodarek i zagregowane statystyki dla reszty świata dla lat 1995-2011 [WIOD, 2013].

Trzeci projekt, znany pod nazwą EORA, powstał z inicjatywy UNCTAD [2015]. $W$ bazie zgromadzono dane statystyczne o krajowej i zagranicznej wartości dodanej dla 187 krajów, a zakres czasowy obejmuje lata 1990-2012.

\section{Główne tendencje w kształtowaniu się wartości i dynamiki handlu międzynarodowego w latach 2008-2016}

Kryzys gospodarczy lat 2008-2009 spowodował największe załamanie handlu międzynarodowego w okresie po II wojnie światowej. Wartość światowego eksportu spadła w 2009 r. o 22,2\%, a załamanie miało charakter powszechny i dotyczyło praktycznie wszystkich krajów świata. Zgodnie z danymi UNCTAD [2018] wśród najważniejszych uczestników wymiany największe spadki dotyczyły Japonii $(-25,7 \%)$ i Niemiec (-22,6\%). Wartość eksportu Stanów Zjednoczonych spadła o $18,0 \%$, a Chin o $16,0 \%$. 
Ożywienie handlu międzynarodowego nastąpiło już w II kwartale 2009 r., a wartość eksportu rosła do III kwartału 2011 r. (rys. 2). Niestety wzrostowa tendencja zatrzymała się w IV kwartale 2011 r. i do połowy 2014 r. rozwój eksportu uległ stagnacji. Od III kwartału 2014 r. jego wartość zaczęła maleć, a spadek trwał do I kwartału 2016 r. W kolejnych kwartałach utrzymywała się tendencja wzrostowa. Zdaniem eksportów UNCTAD obecny wzrost wartości eksportu spowodowany jest ożywieniem gospodarczym w dynamicznie rozwijających się krajach Azji oraz wzrostem importu w Stanach Zjednoczonych i Ameryce Łacińskiej, zwłaszcza na przełomie lat 2016 i 2017. W przypadku Europy ciągle dominują tendencje stagnacyjne [UNCTAD, 2017, s. 6].

Prognozy ekspertów Międzynarodowego Funduszu Walutowego na lata 2018-2019 zakładają wzrost wolumenu światowego eksportu dóbr i usług na poziomie odpowiednio 4,6\% i 4,4\% [IMF, 2018, s. 8]. Natomiast Bank Światowy prognozuje wzrost wolumenu światowego eksportu w 2018 r. na poziomie 4,0\%, w 2019 r. - 3,9\% i w 2020 r. - 3,8\% [World Bank, 2018, s. 4]. Równocześnie autorzy cytowanych prognoz zwracają uwagę na możliwe zagrożenia dla wzrostu gospodarczego i wymiany handlowej w postaci ryzyka na rynkach finansowych, ryzyka politycznego czy też możliwego nasilenia protekcjonizmu.

Analiza danych opartych na wartości światowego eksportu nie daje nam pełnego obrazu sytuacji i może prowadzić do błędnych wniosków co do przyczyn stagnacji światowego handlu. Porównanie danych wartościowych z opartymi na

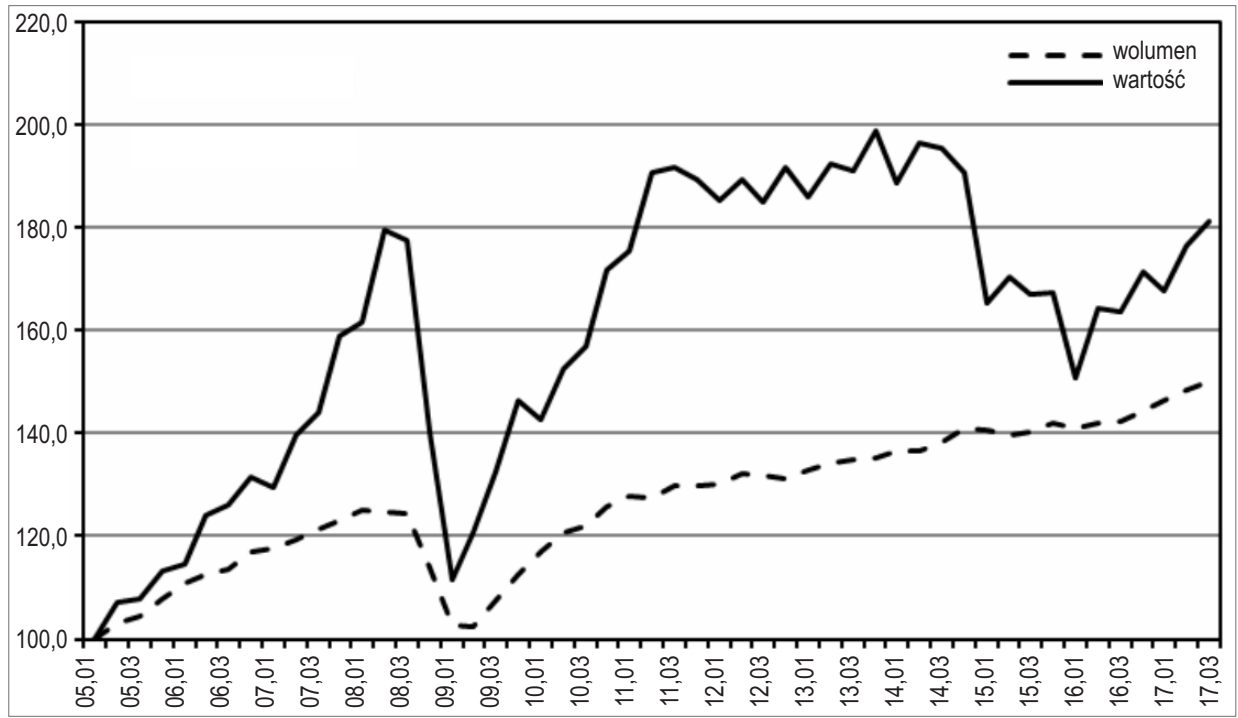

Rysunek 2. Zmiany wartości i wolumenu światowego eksportu w latach 2005-2017, I kwartał $2005=100$

Źródło: [WTO, 2018]. 
wolumenie obrotów pokazuje, że spadek wartości światowego eksportu spowodowany jest w znacznym stopniu tendencjami deflacyjnymi. Świadczy o tym rosnaccy wolumen światowego eksportu oraz dane statystyczne. Eksperci Światowej Organizacji Handlu podają, że w latach 2013-2015 wzrost wartości światowego eksportu był ujemny $(-3,6 \%)$, jednak w ujęciu wolumenowym osiągnięto wzrost na poziomie $2,6 \%$, a spadek wartości był spowodowany wyłącznie ujemnym wzrostem wartości jednostkowej (-6,0\%) [WTO, 2016, s. 22]. W największym stopniu do spadku wartości światowego eksportu przyczynił się spadek cen surowców energetycznych, a zwłaszcza ropy naftowej. W latach 2008-2016 jej ceny spadły o $56 \%$, ceny minerałów i metali nieżelaznych o $29 \%$, żywności i napojów o 7\%, a ceny surowców rolnych pozostały na niezmienionym poziomie [WTO, 2017, s. 175].

Wśród pozostałych czynników spowolnienia handlu międzynarodowego wymienia się również osłabienie światowego popytu inwestycyjnego. Wskazują na to m.in. eksperci Międzynarodowego Funduszu Walutowego, którzy szacują, że niską dynamikę wzrostu realnego importu towarowego w latach 2012-2015 można w około 75\% wyjaśnić słabą aktywnością gospodarczą, a zwłaszcza spadkiem inwestycji [IMF, 2016, s. 65]. Na kluczowe znaczenie analogicznych czynników uwagę zwraca również Larry Summers. Sformułował on koncepcję nowej sekularnej stagnacji, zgodnie z którą niskie tempo wzrostu gospodarczego jest spowodowane zbyt wysokimi oszczędnościami i niewystarczającymi inwestycjami. Z kolei niskie inwestycje powodują załamanie popytu na import i spadek światowej wymiany handlowej [Summers, 2014].

Kolejnym wymienianym czynnikiem jest brak postępów w liberalizacji handlu oraz nasilenie tendencji protekcjonistycznych. Jednak dostępne wyniki analiz empirycznych nie potwierdzają istotnego wzrostu protekcjonizmu i raczej marginalizują jego wpływ na spadek obrotów [Wojtas, 2017].

Ostatnim czynnikiem będącym przedmiotem analizy w niniejszym opracowaniu jest osłabienie powiązań produkcyjnych między głównymi uczestnikami handlu międzynarodowego.

\section{Osłabienie powiązań produkcyjnych i spadek znaczenia zagranicznej wartości dodanej w handlu międzynarodowym}

Oceniając tendencje w kształtowaniu się udziału zagranicznej wartości dodanej w światowym eksporcie, możemy wskazać na pewne prawidłowości. Przede wszystkim, bez względu na wykorzystywane dane (WIOD, EORA, WTO-OECD), udział zagranicznej wartości dodanej w eksporcie światowym brutto charakteryzował się w latach 1995-2008 wyraźną tendencją wzrostową. W 2008 r. udział 
zagranicznej wartości dodanej w światowym eksporcie towarowym obliczony na podstawie danych WIOD wynosił 24,8\%. Zbliżony poziom oszacowano na podstawie danych WTO-OECD (24,2\%). Natomiast dane pochodzące z bazy EORA tradycyjnie podają wyższe wskaźniki (w 2008 r. 31,0\%) (rys. 3).

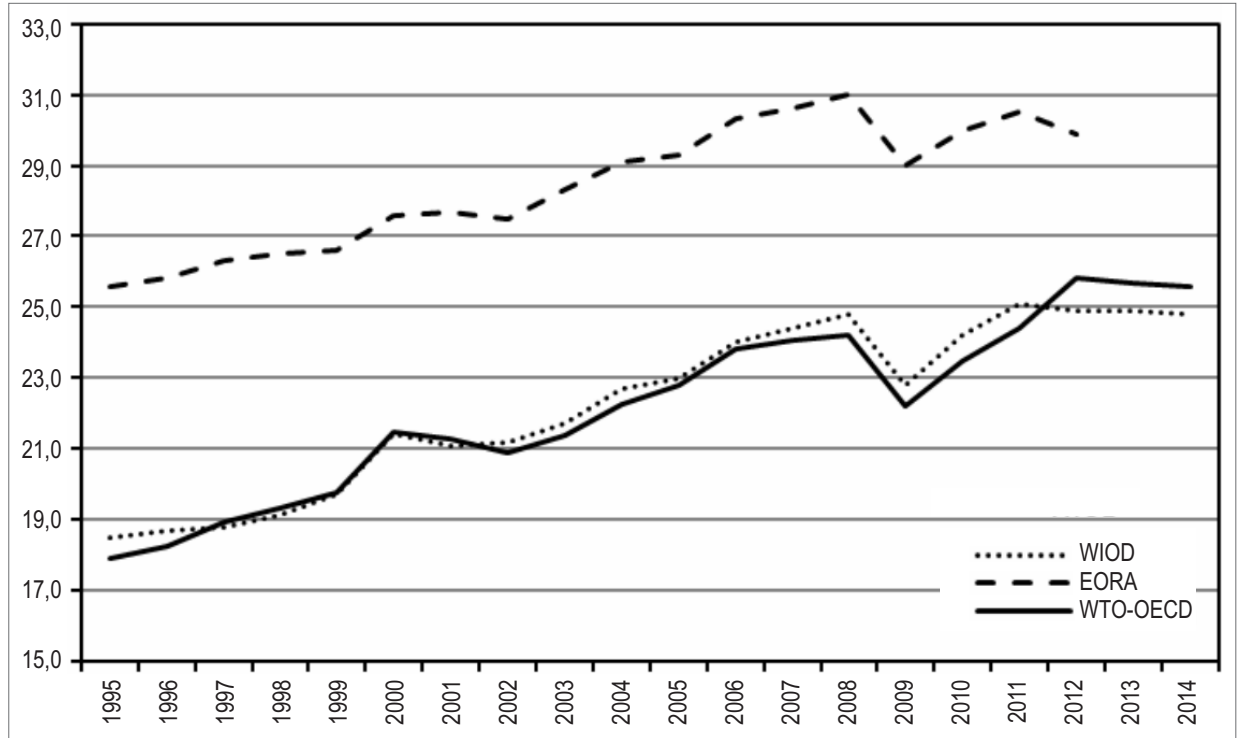

Rysunek 3. Udział zagranicznej wartości dodanej w światowym eksporcie brutto w latach 1995-2014 (w \%)

Uwagi: Dane WIOD pochodzą z dwóch wersji bazy. Dla lat 1995-1999 z bazy WIOD 2013, dla okresu po roku 2000 z bazy WIOD 2016. Różnią się one w niewielkim stopniu klasyfikacją przemysłów i liczbą krajów. Dane OECD-WTO dla lat 1995-2011 pochodzą z bazy z grudnia 2016 r. Dla lat 2012-2014 zostały oszacowane przez eksportów OECD i WTO oraz poddane ekstrapolacji dla grupy krajów określanej jako reszta świata. Jej udział w światowej zagranicznej wartości dodanej w latach 1995-2011 mieścił się w przedziale 3,5-5,6\%, a w eksporcie brutto 4,9-8,7\%.

Źródło: Obliczenia własne na podstawie danych: [OECD-WTO, 2016; WIOD, 2013; WIOD, 2016; UNCTAD, 2015].

Wskutek kryzysu gospodarczego lat 2008-2009 nastąpiło załamanie handlu międzynarodowego, ale również istotnie spadł udział zagranicznych komponentów i podzespołów w eksporcie brutto. Świadczy to o dużym spadku wartości światowego handlu dobrami pośrednimi, większym niż eksportu całkowitego. Załamanie nie było jednak długotrwałe i już w 2010 r. udział zagranicznej wartości dodanej ponownie zaczął rosnąć. Wzrostowa tendencja utrzymała się do $2011 \mathrm{r}$. (zgodnie z danymi WTO-OECD do 2012 r.), a następnie wyhamowała. Najnowsze dostępne dane pozwalają oszacować udział zagranicznej wartości dodanej w roku 2014 na poziomie od 24,8\% (WIOD) do 25,6\% (WTO-OECD). 
Podobnych wniosków dostarczają wyniki, jakie uzyskali Marcel Timmer, Bart Los, Robert Stehrer oraz Gaaitzen de Vries [Timmer i in., 2016], opierając się na bazie WIOD. Zaproponowali oni nową metodę mierzenia fragmentacji produkcji, a zastosowany wskaźnik nazwali Global Import Intensity (GII). Mierzy on import podzespołów, surowców i części potrzebnych we wszystkich stadiach procesu produkcji. Poziom wskaźnika GII rósł w latach 2000-2008, osiągając w 2008 r. 33\%. W 2009 r. nastąpił jego spadek o około 5 p.p., a od 2011 r. wskaźnik ustabilizował się na poziomie około 30\%, jednak tendencja jest spadkowa [Timmer i in., 2016, s. 5]. Jak wskazują Timmer i inni, gdy GII maleje, elastyczność dochodowa importu jest mniejsza niż 1 .

Czy zatem uprawniona jest teza o refragmentacji lub zatrzymaniu procesu fragmentacji produkcji? Aby odpowiedzieć na tak postawione pytanie, należy dokładniej określić zmiany udziału zagranicznej wartości dodanej w eksporcie brutto w głównych ośrodkach gospodarki światowej. Zdaniem Richarda Baldwina możemy wyróżnić trzy centra produkcyjne zlokalizowane w Azji, Europie i Ameryce Północnej, zorganizowane odpowiednio wokół Japonii i Chin, Niemiec oraz Stanów Zjednoczonych [Baldwin, 2013]. Istnieją liczne przesłanki pozwalające sądzić, że kluczowy wpływ na zachodzące w ostatnich latach zmiany mają Chiny, a zwłaszcza przemiany $\mathrm{w}$ ich specjalizacji pionowej [Constantinescu, Mattoo, Ruta, 2015]. W przypadku Europy i Stanów Zjednoczonych nie odnotowano aż tak radykalnych przeobrażeń.

Postęp technologiczny, jaki dokonuje się od połowy lat dziewięćdziesiątych XX w., wyrażający się w rozwoju nowoczesnych metod komunikacji i przesyłania danych oraz w spadku kosztów transportu, a także liberalizacja polityki handlowej w wielu krajach rozwijających się ułatwiły rozwój procesu fragmentaryzacji produkcji. W znacznym stopniu zjawisko to dotyczyło Chin. Importowały one części i podzespoły z wyżej rozwiniętych gospodarek, a następnie przy ich wykorzystaniu wytwarzały dobra finalne, eksportowane dalej głównie do Stanów Zjednoczonych i Europy Zachodniej [Amiti, Freund, 2010; Białowąs, 2014]. Świadczy o tym bardzo wysoki udział importowanych części i komponentów w eksporcie Chin, który aż do 2003 r. charakteryzował się tendencją rosnącą (rys. 4).

Na podstawie bazy danych UN Comtrade możemy oszacować udział importowanych komponentów i części w eksporcie Chin w latach 1998-2016. Z przedstawionych na rysunku 4 danych wynika, że w latach 1998-2003 udział ten wzrósł z 49,3\% do 55,6\%. W 2004 r. pojawiła się silna tendencja spadkowa, trwająca do 2008 r. Po roku 2009 udział części i komponentów w eksporcie Chin podlega pewnym, relatywnie niewielkim, wahaniom i mieści się w przedziale $37-43 \%$.

Podobne wnioski możemy wyciągnąć na podstawie analizy danych o udziale zagranicznej wartości dodanej w eksporcie Chin. Udział ten wzrósł z 35,9\% w 2000 r. do 38,7\% w 2003 r. [OECD-WTO, 2016]. W latach 2004-2009 dominowała tendencja spadkowa, a na koniec okresu opisywany wskaźnik osiągnął $30,8 \%$. Od 
2010 r. udział zagranicznej wartości dodanej ustabilizował się na poziomie $30-31 \%$. W 2014 r. wynosił on $29,4 \%$, co było najniższym wynikiem w całym analizowanym okresie.

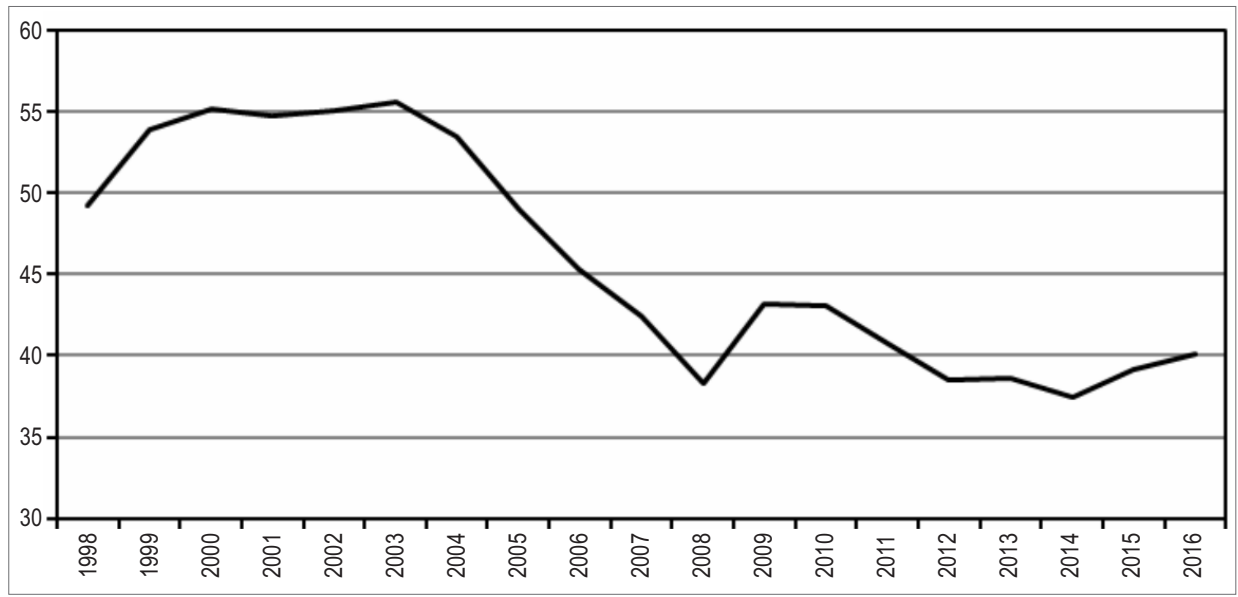

Rysunek 4. Udział importowanych części i komponentów w eksporcie Chin w latach 1998-2016 (w \%)

Uwagi: Klasyfikacja części i komponentów oparta jest na metodzie BEC. Dane pochodzą z bazy UN Comtrade i uwzględniają trzy kategorie: 22, 42 i 53.

Źródło: Obliczenia własne na podstawie danych: [UN Comtrade, 2018].

Do interesujących wniosków na temat spadku udziału zagranicznej wartości dodanej (i wzrostu krajowej wartości dodanej) w eksporcie Chin doszli Hiau Kee oraz Heiwang Tang [2016]. Analizując dane pochodzące z chińskich przedsiębiorstw z lat 2000-2007 wykazali, że udział krajowej wartości dodanej w eksporcie wzrósł w przypadku prawie wszystkich przemysłów za wyją̨tkiem produkcji drewna i wyrobów drewnianych oraz metali podstawowych. Stwierdzili również, że udział krajowej wartości dodanej w eksporcie do pięciu głównych partnerów handlowych (Stany Zjednoczone, Hongkong, Japonia, Korea Płd. i Niemcy) wzrósł w analizowanym okresie średnio o około 10 p.p. Na podstawie ekonometrycznej analizy szeregów czasowych Kee i Tang wykazali, że głównymi czynnikami wzrostu udziału krajowej wartości dodanej w eksporcie były obniżki taryf celnych oraz napływ zagranicznych inwestycji bezpośrednich.

W przypadku Stanów Zjednoczonych udział zagranicznej wartości dodanej wykazuje silną procykliczoność i jest wyraźnie skorelowany z tempem wzrostu gospodarczego. Istotne spadki wystąpiły w okresie kryzysu firm „nowej gospodarki" w latach 2001-2003 oraz w roku 2009. Jednak od 2011 r. udział FVA w eksporcie brutto utrzymuje się na stabilnym poziomie, przekraczającym 15\% [OECD-WTO, 2016]. 
Również w krajach UE-28 i Niemczech niewielkie spadki zagranicznej wartości dodanej wystąpiły jedynie w latach 2001-2003 oraz w roku 2009. Zatem to przede wszystkim osłabienie powiązań produkcyjnych między Chinami a innymi gospodarkami powoduje spadek udziału FVA w eksporcie światowym oraz osłabienie relacji wiążących handel z PKB.

\section{Podsumowanie}

Przeprowadzona analiza wpływu osłabienia powiązań produkcyjnych w gospodarce światowej na spowolnienie handlu międzynarodowego po kryzysie lat 2008-2009 pozwala na sformułowanie kilku wniosków. Po pierwsze, stagnacja handlu międzynarodowego jest rezultatem nie tylko niskiego wzrostu światowego PKB i popytu na głównych rynkach świata, ale przede wszystkim zmian strukturalnych zachodzących w relacjach światowego eksportu i globalnego PKB. Świadczą o tym spadki dochodowej elastyczności eksportu, która przyjmuje w ostatnich latach wartości mniejsze od 1.

Po drugie, wśród możliwych przyczyn tego zjawiska wymienia się zmiany strukturalne w światowym handlu i PKB oraz wzrost protekcjonizmu. Przeprowadzone analizy wskazują jednak na istotną rolę zmian zachodzących w międzynarodowych powiązaniach produkcyjnych, a zwłaszcza w globalnym handlu wartością dodaną. Udział zagranicznej wartości dodanej w światowym eksporcie brutto istotnie spadł po roku 2009, a następnie po szybkim odbiciu ustabilizował się. W przeciwieństwie jednak do okresu sprzed roku 2008 nie wykazuje on już tendencji rosnącej.

Po trzecie, analiza zmian udziału zagranicznej wartości dodanej w eksporcie brutto na trzech głównych rynkach pokazuje, że osłabienie powiązań produkcyjnych w Stanach Zjednoczonych i Unii Europejskiej wystąpiło jedynie w okresie kryzysu gospodarczego, a po 2009 r. udział FVA w eksporcie ponownie wzrósł. W przypadku Chin obserwujemy natomiast wyraźną tendencję spadkową, która rozpoczęła się już w 2004 r. Świadczy to o tym, że Chiny w coraz większym stopniu wykorzystują krajowe komponenty, co wpływa na osłabienie powiązań produkcyjnych w regionie Azji, ale również ze Stanami Zjednoczonymi i krajami UE.

\section{Bibliografia}

Amiti M., Freund C., 2010, The Anatomy of China's Export Growth, [w:] China's Growing Role in the World Trade, eds. R.C. Feenstra, S.-J. Wei, Chicago - London.

Balassa B., 1967, Trade Liberalization Among Industrial Countries, McGraw-Hill, New York. Baldwin R., 2013, Global Supply Chains. Why They Emerged, Why They Matter, and Why They Are Going, [w:] Global Value Chains in a Changing World, eds. D. Elms, P. Low, WTO, Geneva. 
Białowąs T., 2014, Outsourcing a rzeczywista przewaga komparatywna Chin w światowym handlu, [w:] W kierunku nowego ładu gospodarczego - rola Azji w XXI wieku, red. J. Marszałek-Kawa, R. Gawłowski, Wydawnictwo Adam Marszałek, Toruń.

Constantinescu C., Mattoo A., Ruta M., 2015, The Global Trade Slowdown. Cyclical or Structural?, World Bank Policy Research Working Paper, no. 7158.

Findlay R., 1978, An "Austrian" Model of International Trade and Interest Rate Equalization, Journal of Political Economy, no. 6.

Gereffi G., Humphrey J., Sturgeon T., 2005, The governance of global value chains, Review of International Political Economy, no 1.

Gereffi G., Korzeniewicz M., Korzeniewicz R., 1994, Introduction. Global Commodity Chains, [w:] Commodity Chains and Global Capitalism, eds. G. Gereffi, M. Korzeniewicz, Praeger, Westport - London.

Hopkins T.K., Wallerstein I., 1977, Patterns of development of the modern world-system, Review, no. 2.

Hopkins T.K., Wallerstein I., 1986, Commodity chains in the world economy prior to 1800, Review, no. 1.

Hummels D., Ishii J., Yi K.-M., 2001, The nature and growth of vertical specialization in world trade, Journal of International Economics, no. 1.

IMF, 2016, World Economic Outlook. Subdued Demand - Symptoms and Remedies.

IMF, 2018, World Economic Outlook Update January 2018. Brighter Prospects, Optimistic Markets, Challenges Ahead.

Inomata S., 2017, Analytical frameworks for global value chains. An overview, [w:] Global Value Chain Development Report 2017. Measuring and Analyzing the Impact of GVCs on Economic Development, World Bank, Washington D.C.

Irwin D.A., 2002, Long-run trends in world trade and income, World Trade Review, vol. 1, no. 1.

Jones R.W., Kierzkowski H., 1990, The Role of Services in Production and International Trade. A theoretical Framework, [w:] The Political Economy of International Trade. Essays in Honour of Robert Mundell, eds. R.W. Jones, A.O. Krueger, MIT Press, Cambridge.

Jones R.W., Kierzkowski H., 2001, A Framework for Fragmentation, [w:] Fragmentation. New Production Patterns in the World Economy, eds. S.W. Arndt, H. Kierzkowski, Oxford University Press, New York.

Kee H.L., Tang H., 2016, Domestic Value Added in Exports. Theory and Firm Evidence from China, American Economic Review, vol. 106, no. 6.

Koopman R., Wang Z., Wei S.-J., 2014, Tracing Value-Added and Double Counting in Gross Exports, American Economic Review, vol. 104, no. 2.

OECD-WTO, 2016, Trade in Value Added, http://stats.oecd.org/ [dostęp: 15.02.2018].

Summers L.H., 2014, Reflections on the "New Secular Stagnation Hypothesis", [w:] Secular Stagnation. Facts, Causes, and Cures, eds. C. Teulings, R. Baldwin, CEPR Press, London.

Timmer M., Los B., Stehrer R., de Vries G.J., 2016, An Anatomy of the Global Trade Slowdown based on the WIOD 2016 Release, GGDC Research Memorandum, no. 162.

UN Comtrade, 2018, https://comtrade.un.org/data [dostęp: 15.02.2018].

UNCTAD, 2015, Eora Trade In Value Added database, http://www.worldmrio.com/UNCTAD EoraTiVA_free.zip [dostęp: 15.02.2018].

UNCTAD, 2017, Trade and Development Report 2017. Beyond Austerity: Towards a Global New Deal. 
UNCTAD, 2018, UNCTADStat, http://unctadstat.unctad.org/wds/ReportFolders/reportFolders.aspx?sCS_ChosenLang=en [dostęp: 15.02.2018].

WIOD, 2013, 2013 Release, http://www.wiod.org/release13/ [dostęp: 15.02.2018].

WIOD, 2016, 2016 Release, http://www.wiod.org/release16/ [dostęp: 15.02.2018].

Wojtas M., 2017, Przyczyny spowolnienia światowego handlu, Studia i Prace WNEiZUS, nr 49/2.

World Bank, 2018, Global Economic Prospects January 2018. Broad-Based Upturn, but for How Long?

WTO, 2016, World Trade Statistical Review 2016.

WTO, 2017, World Trade Statistical Review 2017.

WTO, 2018, Short-term trade statistics. Quarterly merchandise trade value, https://www.wto. org/english/res_e/statis_e/daily_update_e/quarterly_trade_e.xls [dostęp: 15.02.2018].

T. Białowąs ( bialowas@hektor.umcs.lublin.pl

Katedra Gospodarki Światowej i Integracji Europejskiej, Wydział Ekonomiczny, Uniwersytet Marii Curie-Skłodowskiej w Lublinie, pl. Marii Curie-Skłodowskiej 5, 20-031 Lublin, Polska 